\title{
REASONS FOR THE OCCURENCE OF SMALL FOREST PATCHES WITHIN POST-GLACIAL AREAS USED FOR AGRICULTURE IN NORTHERN POLAND
}

\author{
PIEŃKOWSKI, P. ${ }^{1 *}-$ PODLASIŃSKI, M. ${ }^{2}-$ SZPIGIEL, M. ${ }^{1}$ \\ ${ }^{1}$ Department of Ecology, Environmental Protection and Management, West Pomeranian \\ University of Technology in Szczecin, al. Piastów 17, 70-310 Szczecin, Poland \\ ${ }^{2}$ Department of Soil Science, Grasslands and Environmental Chemistry, West Pomeranian \\ University of Technology in Szczecin, al. Piastów 17, 70-310 Szczecin, Poland \\ *Corresponding author \\ e-mail: pawel.pienkowski@zut.edu.pl; phone: +48-91-449-6347
}

(Received 25 $5^{\text {th }}$ Apr 2019; accepted $16^{\text {th }}$ Jul 2019)

\begin{abstract}
Small forest patches (SFPs) are considered as one of the most important landscape elements, enriching the monotonous agricultural areas. Various studies focus on the ecological role of SFPs, however none provides a comprehensive characteristics of the reasons for their occurrence in post-glacial areas. The location of SFPs within field areas is not incidental, and the occurrence is mainly determined by physiographic factors which prevent or hinder the use of such areas for agriculture. To a large extent, the distribution of SFPs is determined by the origin of the given area which, in the case of Europe and North America, is related to ice sheets and their effects over millennia. Therefore, the aim of the present paper was the assessment of the reasons for the occurrence of SFPs within intensely cultivated agricultural post-glacial areas in Western Pomerania of Poland. It was found that the occurrence of SFPs is related to natural abiotic factors, the most important being gradient of a slope, presence of sandy soils and wetlands. Additionally, the significance of these factors, size of SFPs and their spatial characteristics to a large degree are determined by geomorphological variability of the area.
\end{abstract}

Keywords: agricultural landscapes, small remnant habitats, landscape management, forest fragmentations, postglacial areas

\section{Introduction}

Small-scale landscape elements, such as small forest patches (SFPs), copses, avenues and scattered trees, constitute significant elements enriching the agricultural areas (Gibbons et al., 2008; van Zanten et al., 2016; Solon et al., 2017). Given the increasing intensification of agricultural activity leading to, among others, depletion of the natural environment heterogeneity, the importance of such elements is increasing (MygaPiatek, 2010). Small forest patches provide, among other things, habitats for various plant and animal species displaced from anthropogenically transformed habitats (Graae, 2000; Lindgren, 2017; Michel et al., 2007; Yahner, 1986; Wuczyński, 2016; Gamrat and Gałczyńska, 2014; Farah et al., 2017; Stanton et al., 2018). Due to their location between larger forest complexes, SFPs act as stepping stone habitats which, similarly to ecological corridors, facilitate connection between landscapes (Jongman, 2002; Burger and Burger, 2005; Estreguil et al., 2013). Small forest patches and mid-field tree stands are considered to be not only an important element of agricultural landscape protection, but also to have a positive effect on biological as well as microclimatic conditions of the surrounding cultivated fields (Zajączkowski, 2005). They also play an important role in both the sequestration and storage of carbon (Brown and Fisher, 2009).

It is believed that intensively used agricultural landscape has a relatively low landscape aesthetic quality (Hermes et al., 2018), that is why numerous authors stress 
the aesthetic and recreation value of SFPs (Arriaza et al., 2004; De Groot, 2006; Van Berkel and Verburg, 2014). In addition, SFPs often provide inspiration and complement cultural heritage (Power, 2010; Schaich et al., 2010; Myga-Piątek, 2012).

The ecological aspect of SFPs was analysed in numerous areas (Baudry et al., 2000; Ryszkowski et al., 2003; Decocq et al., 2016; Varela et al., 2018), however the reasons behind their occurrence within the prevalent agricultural landscape have not yet been fully established. Unarguably, their mid-field location is not incidental and is determined by physiographic factors which prevent or hinder the use of such areas for agriculture. To a large extent, distribution of SFPs is determined by the origin of the given area which, in the case of Europe and North America, is related to ice sheet and its effect over millennia (Fig. 1). Additionally, it is conditioned by anthropogenic impact, including economic considerations (Benoit et al., 2012), form of ownership (Crow et al., 1999), development of technology (Vejre and Brandt, 2004; Romanova, 2015), as well as political reasons (Bell et al., 2009).

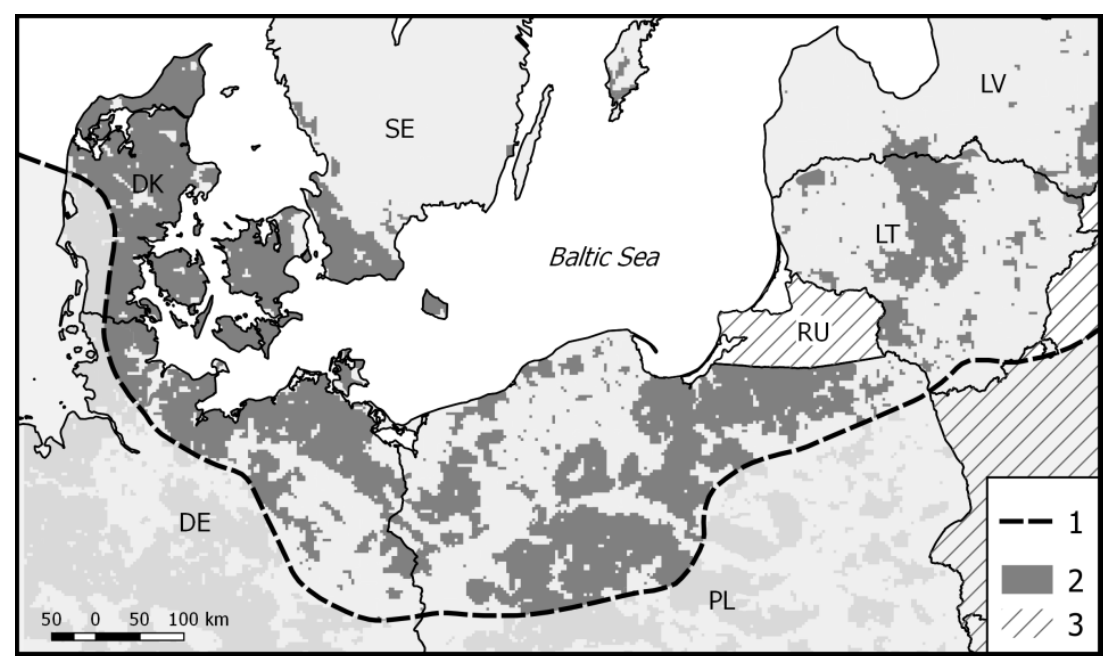

Figure 1. Predominant agricultural landscape in the area of the last glacial period (based on Corine Land Cover 2000). 1 - limit of Weichselian glaciations, 2 - agricultural landscape, 3 outside data coverage

Within the area of intensively used agricultural landscape, the morphological features resulting from glacier retreat (terminal moraines, kames, eskers, dead-ice depression, tunnel valleys) determine the occurrence of small landscape elements including patches of sandy soils, non-runoff depressions (Pieńkowski, 2008) and steep slopes (Najwer et al., 2016). Post-glacial agricultural landscape is additionally diversified by the presence of linear forms, usually not related to physiography, e.g. roadside alleys and hedges (Lenschow, 2005). Given the increasing intensification of agricultural actions, all these forms are in danger of disappearing (Agger and Brandt, 1988; Pieńkowski et al., 2010; Kühne, 2018). It is estimated that in the 2009-2015 period alone, there was a decline in farmland area important to biodiversity in Germany of nearly $13 \%$ which, consequently, brought a reduction in the number of trees, hedges, copses and ditches (Agriculture Report, 2017).

Paradoxically, a continuous increase in tree stands has been observed in Europe since the 1960s (European Environment Agency, 2017). An increase in the forest area is also observed in post-glacial areas in Poland (Zając et al., 2014; Pieńkowski, 2015), and the 
increase rate depends on the region (Żarska et al., 2016; Ciesielska and Ciesielski, 2017). However, global increase in forested area is mainly connected with expansion and consolidation of larger patches in the areas of soils of poor quality and does not apply to intensively cultivated areas, where the number of small and isolated forest patches is decreasing (Brown and Fisher, 2009).

The observed landscape simplification leads to reduction in ecosystem services on which agriculture depends. It is assumed that designing agricultural landscapes requires determination of the desired ecosystem services, evaluation of current landscape structure and implementation of targeted modifications (Landis, 2017). It seems reasonable to argue that determination of physiographical diversity of agricultural landscapes and identifying spatial elements determining the presence and distribution of potential biotopes characteristic for SFPs would be beneficial.

For all the reasons outlined above, the aim of the present paper was an attempt to distinguish these elements with respect to small forest patches. The authors believe that such identification and determination of spatial distribution can provide a significant criterion to be adopted in agricultural landscape planning.

\section{Characteristics of the study area}

The studied area of Western Pomerania is situated at $52^{\circ} 51^{\prime} \mathrm{N}$ and $54^{\circ} 06^{\prime} \mathrm{N}$ to $14^{\circ}$ $31^{\prime} \mathrm{E}$ and $16^{\circ} 17^{\prime} \mathrm{E}$ and covers the fragments of three macro-regions in Poland: South Pomeranian Lakeland, West Pomeranian Lakeland and the Szczecin Coastal Region. Land relief of these areas is the result of Scandinavian ice sheet in the Pleistocene glaciation. Therefore, predominant are sedimentary rocks of glacial (loam, sandy loam) and fluvial origin (sand). The effect of marine environment on the climate of this area is significant, as the mean air temperature in winter drops to just below $0{ }^{\circ} \mathrm{C}$, whereas the mean annual air temperature amounts to $8.5^{\circ} \mathrm{C}$ and is only slightly higher than the average for Poland. Mean annual precipitation sum amounts to $600-650 \mathrm{~mm}$ and precipitation occurring in the summer months is prevalent.

The current landscape was formed primarily in the last 16 thousand years, when in the vicinity of retreating glacier, a complex of post-glacial forms began to form as a result of ice sheet and meltwaters activity. Following the climatic change, the developing natural vegetation was preserved only partially, and the existing forest complexes in Western Pomerania are not of primary forest nature. Nevertheless, forest vegetation was found in great majority of areas of Pomerania. Only wetlands, inundated by floods and coastal quicksand were not covered by forest vegetation. With agricultural development and expansion of settlements, the area of cultivated lands increased, which was coupled with a decrease and fragmentation of the forest area. Changes with respect to intensity of land use were mainly determined by the type of soil. The largest forest complexes remained on sandy terrace plains, outwash plains and terminal moraines, whereas in morainic uplands agricultural use was, and still is, predominant (Pieńkowski and Podlasiński, 2002). At present, forest coverage of this area is $36.5 \%$ with pine tree being dominant in forests and Pomeranian beech forests in more fertile habitats. Agricultural use of land reaches $36.7 \%$ with cereals (mainly wheat) as the prevent crop followed by rapeseed, corn and sugar beet.

The six study sites (Fig. 2) were characterised by predominance of agricultural landscape and the largest number of SFPs areas, as compared with other locations. Selected characteristics of testing sites are presented in Table 1. Morainic upland is the 
prevalent area, similarly to the whole region of Pomerania, particularly in the area of post-glacial agricultural landscape, where soils developed from loamy sands and clays.

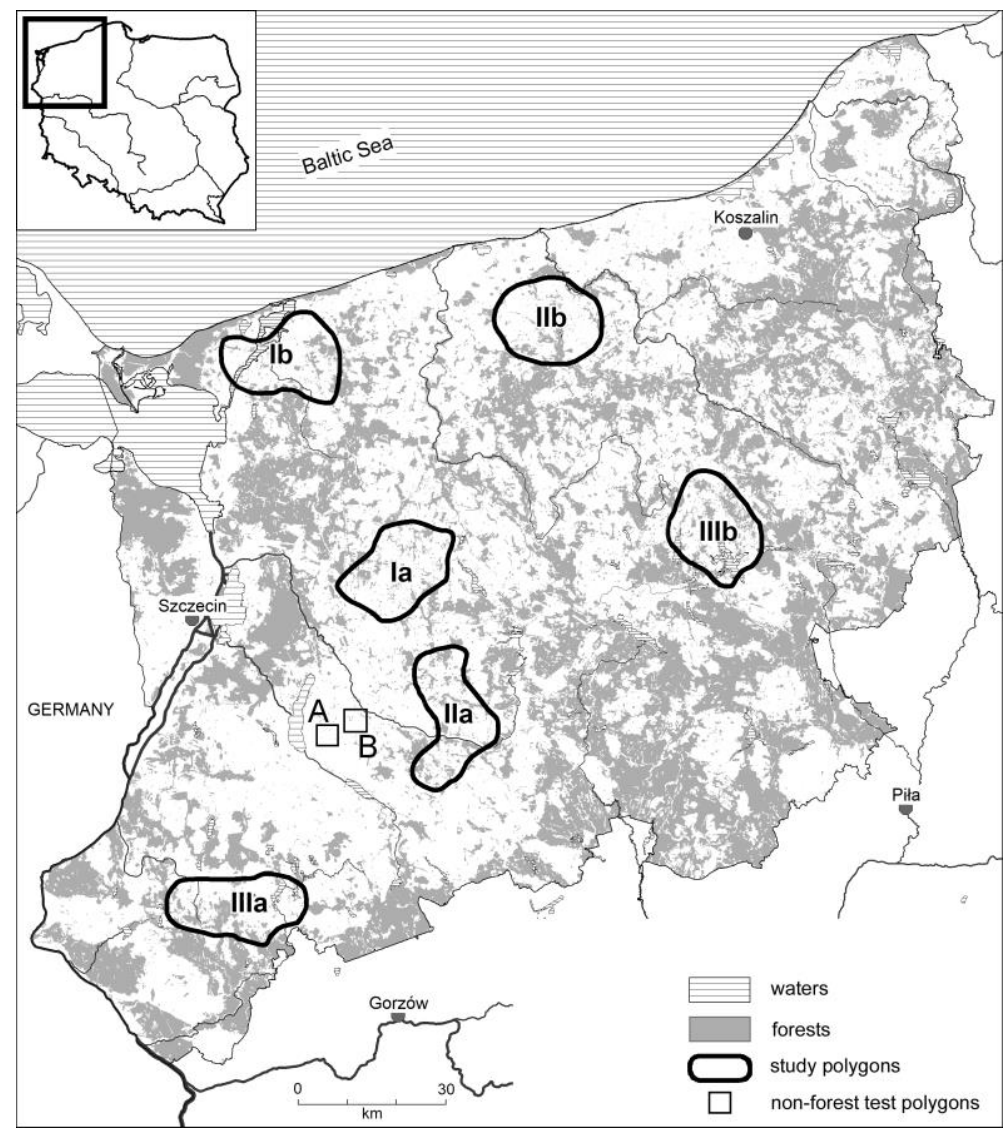

Figure 2. Study sites in the selected area of Western Pomerania

Table 1. Selected properties of study polygons

\begin{tabular}{c|c|c|c|c|c}
\hline $\begin{array}{c}\text { Number of } \\
\text { polygons }\end{array}$ & $\begin{array}{c}\text { Area } \\
{\left[\mathbf{k m}^{2}\right]}\end{array}$ & \multicolumn{2}{|c|}{$\begin{array}{c}\text { Coordinates of polygon } \\
\text { centroids }\end{array}$} & $\begin{array}{c}\text { Range of height } \\
{[\mathbf{m}]}\end{array}$ & $\begin{array}{c}\text { Woodiness } \\
{[\%]}\end{array}$ \\
\hline Ia & 301.1 & $15^{\circ} 12^{\prime} 15^{\prime \prime} \mathrm{E}$ & $53^{\circ} 35^{\prime} 45^{\prime \prime} \mathrm{N}$ & $44.0-116.7$ & 16.7 \\
Ib & 301.1 & $14^{\circ} 46^{\prime} 10^{\prime \prime} \mathrm{E}$ & $53^{\circ} 56^{\prime} 02^{\prime \prime} \mathrm{N}$ & $0.0-31.8$ & 15.0 \\
IIa & 301.2 & $15^{\circ} 22^{\prime} 45^{\prime \prime} \mathrm{E}$ & $53^{\circ} 18^{\prime} 00^{\prime \prime} \mathrm{N}$ & $27.0-103.0$ & 23.1 \\
IIb & 301.1 & $15^{\circ} 35^{\prime} 45^{\prime} \mathrm{E}$ & $54^{\circ} 01^{\prime} 40^{\prime \prime} \mathrm{N}$ & $3.1-85.0$ & 18.2 \\
IIIa & 301.0 & $14^{\circ} 46^{\prime} 10^{\prime \prime} \mathrm{E}$ & $52^{\circ} 55^{\prime} 50^{\prime \prime} \mathrm{N}$ & $51.0-111.5$ & 21.8 \\
IIIb & 301.0 & $16^{\circ} 08^{\prime} 30^{\prime \prime} \mathrm{E}$ & $53^{\circ} 39^{\prime} 10^{\prime \prime} \mathrm{N}$ & $8.0-221.6$ & 25.4 \\
\hline A & 9.0 & $15^{\circ} 01^{\prime} 30^{\prime \prime} \mathrm{E}$ & $53^{\circ} 15^{\prime} 20^{\prime \prime} \mathrm{N}$ & $26.7-38.0$ & 0.0 \\
B & 9.0 & $15^{\circ} 04^{\prime} 50^{\prime \prime} \mathrm{E}$ & $53^{\circ} 16^{\prime} 05^{\prime} \mathrm{N}$ & $21.0-42.9$ & 1.1 \\
\hline
\end{tabular}

The distinct nature of relief of the six selected study sites is to a large extent connected with diverse hypsometry. In the regions with high share of terminal moraines, there is a higher ratio of areas with surface inclination of more than $5 \%$. The regions dominated by bottom moraines are characterised by areas of smaller inclination (Table 2). Among the analysed study sites, the greatest variability in terms of relief was 
identified in site IIIb where areas of inclination of $5-10 \%$ covered $27.9 \%$ of the whole area. This was due to the presence of numerous terminal moraine hills in this region. The smallest terrain variability was identified in sites $\mathrm{Ia}$ and $\mathrm{Ib}$ where flat upland moraine is predominant. It is worth mentioning that all selected study sites were located outside large outwash plain patches which, due to poor quality of soil, are generally covered by forest vegetation.

Additionally, two study sites of an area of 900 ha and characterised by a total lack of forest vegetation were identified. In these areas, the method of identification developed in the present paper with the aim of facilitating determination of the potential of a given area for establishing SFPs was used. The area marked in Figure 2 as A covers marginal plain, whereas site B flat upland area.

Table 2. Percentage of average slope in research areas

\begin{tabular}{|c|c|c|c|c|c|c|}
\hline \multirow{2}{*}{ Dominated landform } & \multirow{2}{*}{$\begin{array}{c}\text { Study } \\
\text { area }\end{array}$} & \multicolumn{5}{|c|}{ Slope steepness [\%] } \\
\hline & & 0-5 & $5-10$ & 10-18 & 18-27 & $>27$ \\
\hline \multirow{2}{*}{ I flat upland moraine } & Ia & 98.1 & 1.8 & 0.1 & 0 & 0 \\
\hline & $\mathrm{Ib}$ & 95.3 & 4.3 & 0.4 & 0 & 0 \\
\hline \multirow{2}{*}{ II undulating upland moraine } & IIa & 86.7 & 11.3 & 1.9 & 0.1 & 0 \\
\hline & $\mathrm{IIb}$ & 84.5 & 12.3 & 2.9 & 0.3 & 0 \\
\hline \multirow{2}{*}{ III hummocky upland moraine } & IIIa & 83.7 & 14.5 & 1.7 & 0.1 & 0 \\
\hline & IIIb & 62.3 & 27.9 & 8.1 & 1.3 & 0.4 \\
\hline \multicolumn{2}{|l|}{ Total } & 85.10 & 12.02 & 2.52 & 0.30 & 0.07 \\
\hline
\end{tabular}

\section{Materials and methods}

Areas with the largest number of SFPs within the landscape dominated by agricultural lands were defined by VMapL2 using the analysis assessing the distribution of patches centroids. Hot Spot Analysis module of CrimeStat software was used for this purpose (Smith and Bruce, 2008).

To identify the reasons for occurrence of SFPs, layers of VMapL2 were used in MapInfo software, showing the forest cover from the period 2002-2010, orthophotomaps (from 2010) and digital elevation model (DEM). For the purpose of soil conditions analysis, soil-agricultural maps in the scale 1:5000 were used.

For the assessment of the factor determining the presence of SFPs in a given area, a database was compiled. Single database record included an identifier of a given patch and fields proving characteristics: area [ha], centroid coordinates and the dominant factor determining the existence of a patch (W - land wetness, $\mathrm{S}$ - soil, $\mathrm{H}$ - hypsometry, $\mathrm{O}$ - other) identified by cartographic materials and field observations.

The selected landscape metrics were identified using Fragstats 4.2 software (McGarigal et al., 2012) and the following was calculated:

- AREA_MN - mean area of patches [ha]

- CIRCLE_MN - metrics of the shape of patches showing their complexity; irrespective of the size of patches

- NNS - nearest neighbour distance - mean distance to the closest neighbouring patch $[\mathrm{m}]$

- NNI - nearest neighbour index showing cluster distribution of centroids. 


\section{Results and discussion}

\section{Variable factors determining the existence of small forest patches}

In many places in Europe, forest landscapes consist of patches of different quality, age, size and isolation, embedded in agricultural matrix (Decocq et al., 2016). Numerous authors called attention to the close link between the geomorphological conditions and agricultural or forest use of land (Iverson, 1988; Hietel et al., 2004; Wulf et al., 2010). However, the studies conducted so far concerned relatively large areas and did not include the reasons behind the occurrence of small forest patches. As opposed to large forest complexes, the presence of small forest patches is determined by abiotic components of relatively small sizes and, consequently, is more prone to transformation due to natural and anthropogenic factors. Particularly in northern Europe, numerous units established by ice sheets are characterised by small size. These are, among others, wet depressions, sandy soil enclaves and slopes of small size - the number, size and distribution of which are frequently connected with land relief. As opposed to flat outwash areas where large forest areas are predominant, morainic areas are dominated by agricultural matrix where the effect of abiotic factors on landscape structure, including distribution of SPFs and spatial patterns of fragmentation, is most evident.

The present paper presents the quantitative and qualitative analysis of these factors on a representative sample of 1237 small forest patches. The analysis of topographic and soil-agricultural maps, aerial photography, digital elevation model and field observations allowed to identify factors determining the existence of SFPs within agricultural land. It was found that the occurrence of SFPs was related to the presence of a series of mutually-interacting natural conditions which were grouped in categories (Fig. 3) including factors resulting from:

- Existence of poor soils (S) - of little use for agriculture,

- Area hypsometry $(\mathrm{H})$ - large inclination limiting the agricultural use,

- Excessive land wetness (W) - unfavourable conditions for agricultural use of land.

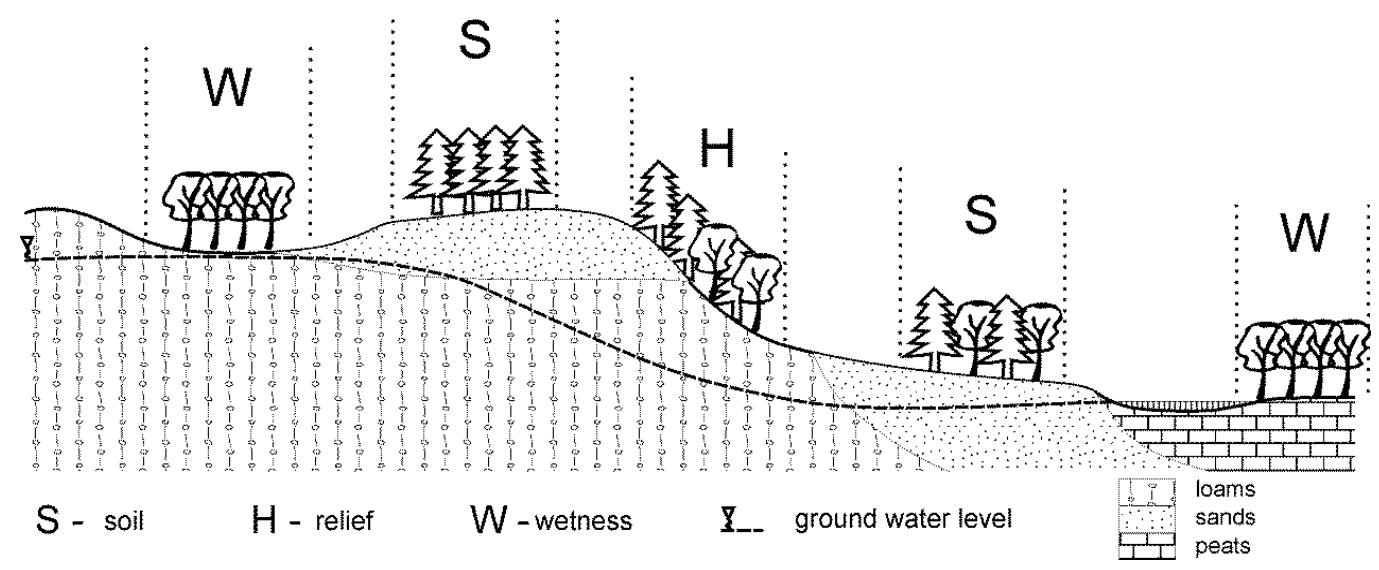

Figure 3. Diagram illustrating the main abiotic factors determining the existence of SFPs

In this paper, the category of "other" $(\mathrm{O})$ was distinguished to group mainly the anthropogenic objects including: manor parks, recreational areas, reclaimed areas or discontinued excavation sites. There were no objects not related to the aforementioned factors, which clearly indicates the fact that, apart from the objects classified as "other", 
the occurrence of SFPs in agricultural landscape is closely related to physiographic conditions preventing the agricultural use of a given area. Due to the fact that the patches were isolated from larger forest complexes and located on arable land, there were no other reasons for their existence - as defined by other authors (Erickson et al., 2002; Najwer et al., 2016) such as: area near existing woods, rocky ground and seasonally flooded area.

The selection of soil factor (S) referred to patches located in areas of undifferentiated hypsometry with soils unfit for agricultural use located on a flat area. However, in the case of forest patches located on the area with clear inclination and, at the same time, poor soil conditions, the determining factor was found to be hypsometry $(\mathrm{H})$. Small forest patches located in wetland areas (most often hydrogenic soils) were classified as belonging to a group of objects related to land wetness factor (W). In only few cases (mainly larger objects), where the individual fragments of patches were determined by different conditions, the factor which affected the existence of the predominant area of a given patch was considered to be the dominant factor. Examples of SFPs with the analysis of reasons for their occurrence is presented in Figure 4.
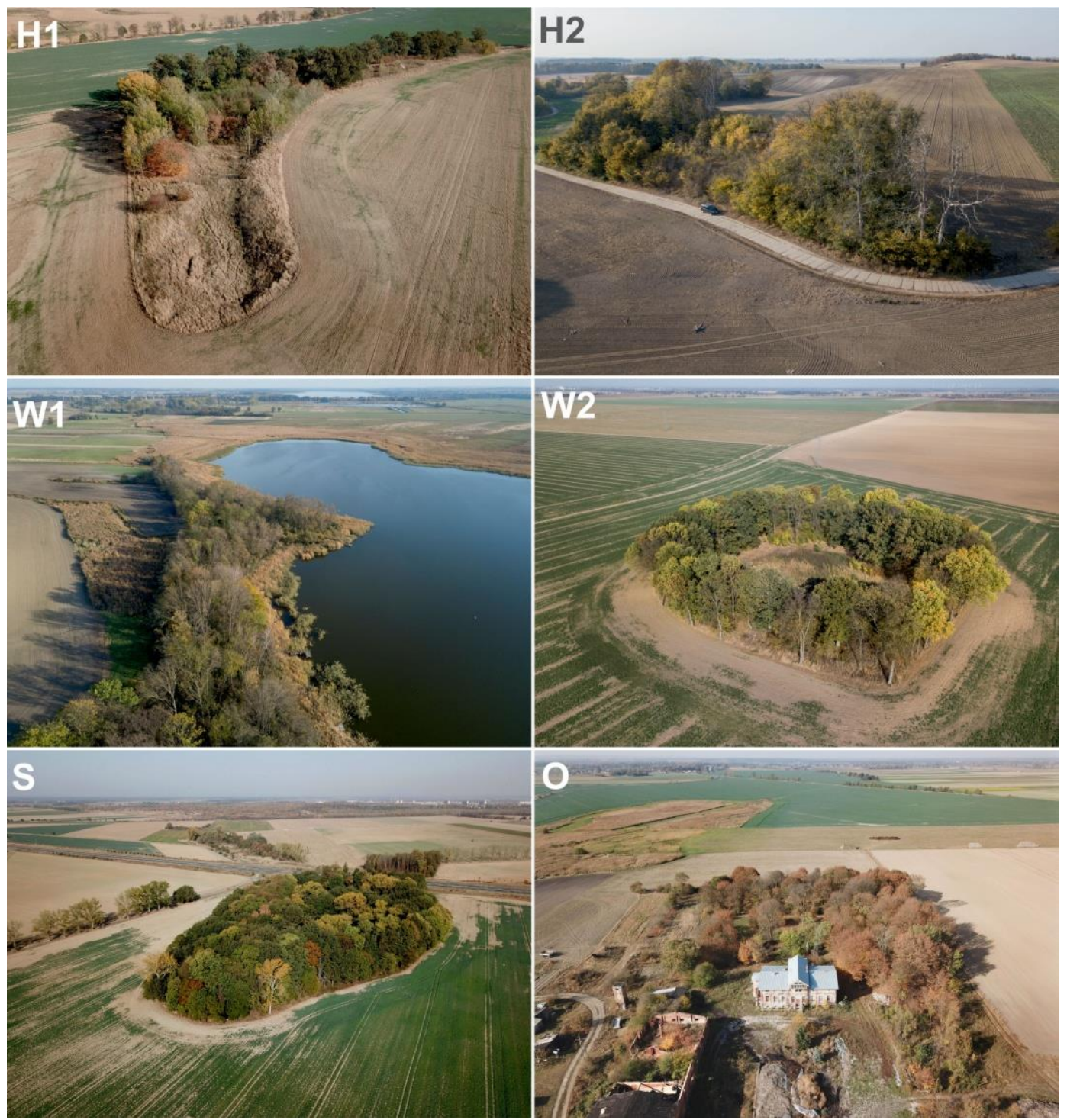

Figure 4. Forest patches in the predominantly agricultural landscape. The reasons for their occurrence: $H$ - relief, $W$-wetness, $S$ - soil, $O$-other 
Variability of the involvement of particular factors affecting the occurrence of SFPs most of all resulted from geomorphological conditions dominating the given area (Figs. 5 and 6 ). In undulating upland area (III), the patches occurring due to high land inclination were predominant. There were, among others, terminal moraine and kame hills of large inclination - more than $25 \%$ in both study sites. In the undulating upland area, the presence of SFPs was also attributed to the occurrence of numerous lakes of steep slopes. In the area IIIb, the patches related to a large altitude gradient constituted more than $50 \%$ of all recorded objects. However, in flat upland (I) and undulating upland (II) areas, the most common cause of SFPs occurrence was land wetness, often connected with the existence of bog. In the study site Ia, numerous bogs were located in Pomeranian marginal-stream valley, and in the study site $\mathrm{Ib}$ - the region of waterlogged subglacial valleys. Within the area of study site IIa, the patches were grouped in the area of the Ina River wide valley, whereas in study site IIb a large share of patches related to land wetness also resulted from the presence of two large bogged subglacial valleys nowadays used as riverbeds. On the slopes of valleys, a relatively large number of patches conditioned by land relief was also identified.

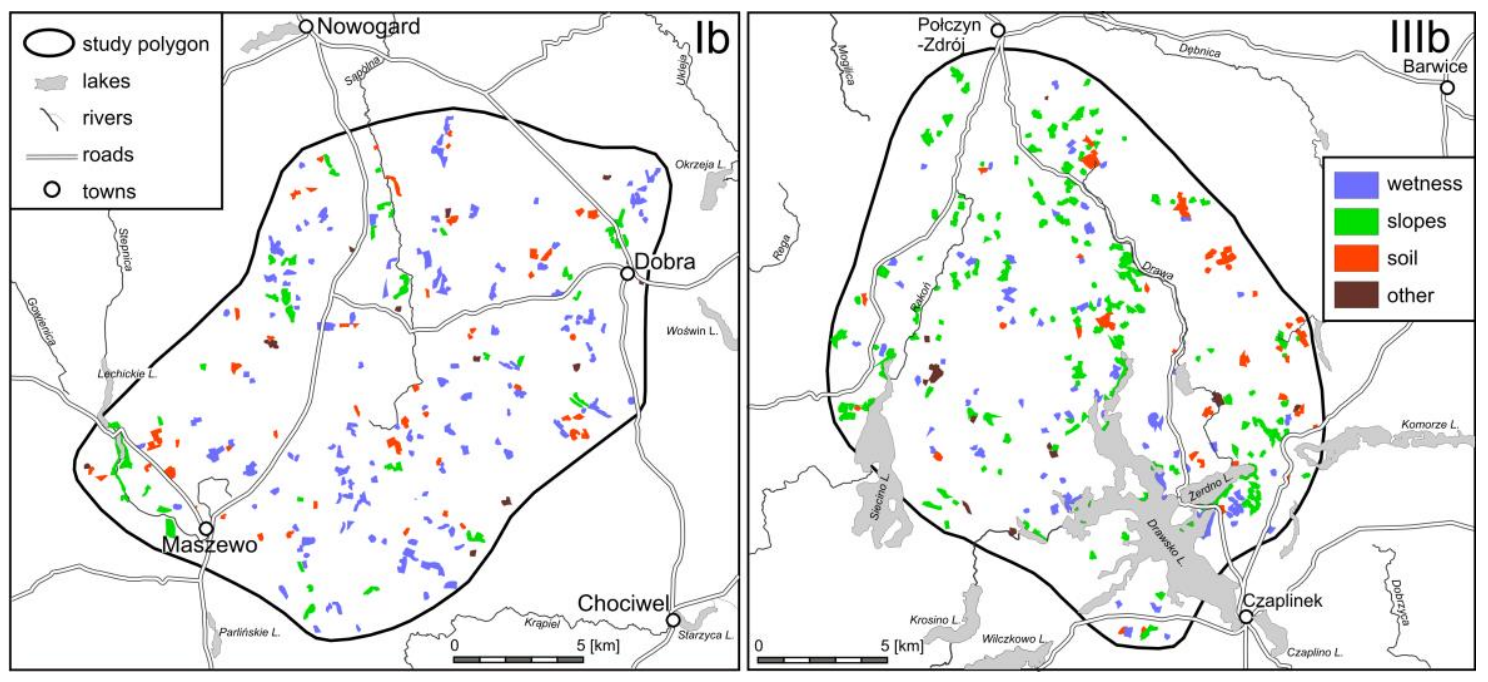

Figure 5. Variability of the factors determining the occurrence of SFPs in the young glacial area of flat (Ib) and hummocky (IIIb) upland

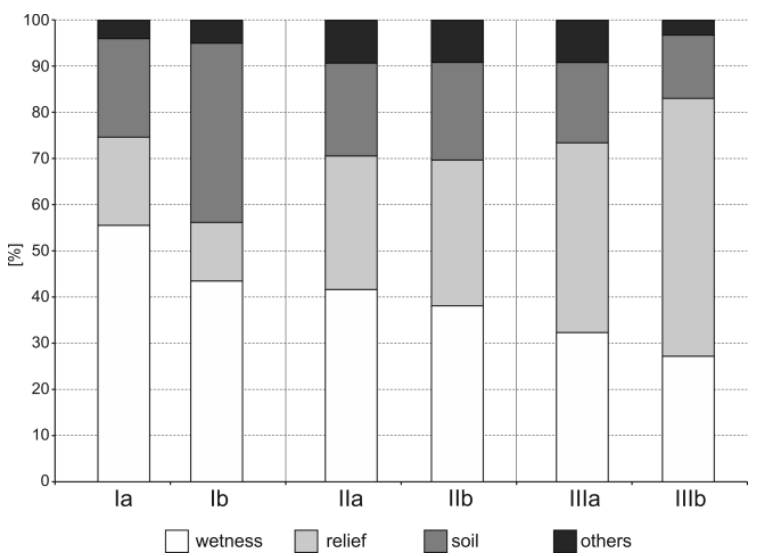

Figure 6. Share of particular elements determining the occurrence of SFPs in the area of study sites 
Relatively high share of SFPs, occurrence of which was related to patches of soils of poor quality (38\%), was found in study site Ia which, in turn, is attributed to the presence of high soil cover mosaicity manifested, among others, by the existence of small compartments of sandy soils.

The selection of the aforementioned factors allowed determination of the areas in terms of potential occurrence of SFPs in agricultural landscape. For this purpose, cartographic materials listed in the Materials and Methods section were used. In identification of the areas three factors were taken into consideration: altitude gradient of more than 15\% which hinders agricultural use of the land (Prus and Budz, 2015), soils of sand granulation and wetlands.

Two study sites were identified in the intensively used agricultural area, characterised by a total lack of forests and SFPs (A and B in Figs. 2 and 7). These study sites are located in Pyrzyckie ice-dammed basin area which was used for agriculture as early as in the Neolithic period (Pospieszny, 2014). This ice-dammed basin constitutes the largest area of open landscape (Plit and Myga-Piątek, 2014). Both study sites are of different origin - study site A includes ice-dam level IV, study site B covers a fragment of flat morainic upland.

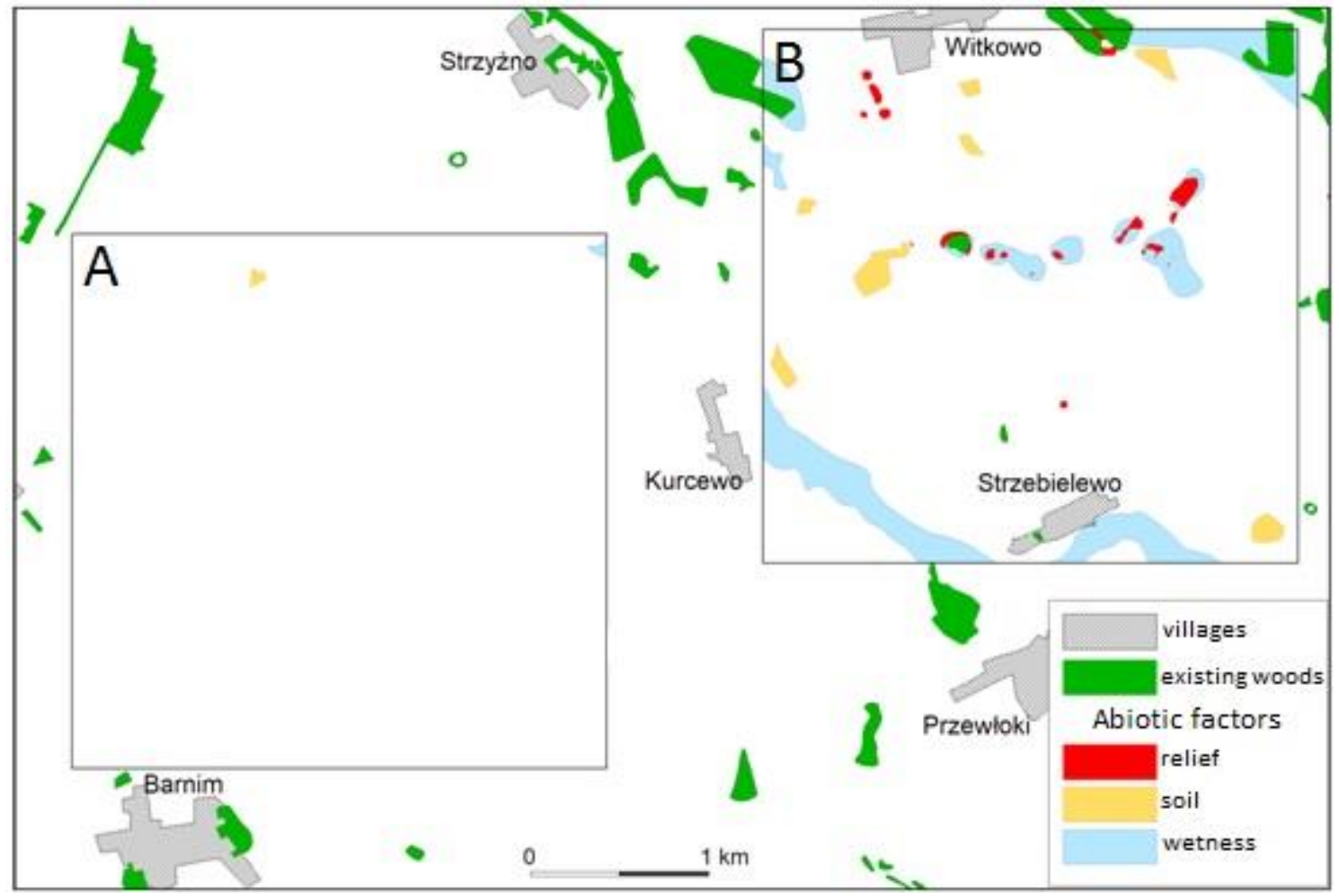

Figure 7. Variability of the potential of two selected areas of Pyrzyckie ice-dammed basin for constituting possible location of SFPs

From the perspective of factors conditioning the presence of SFPs, as adopted in this paper, the potential of both study sites for introducing SFPs to landscape is divergent. The analysis of cartographic materials clearly indicates that the first identified study site (A), with the exception of a small compartment of soils of poor quality, does not provide the conditions for the development of tree cover even in the smallest fragments. 
This is due to homogenous flat area of soils of high quality and optimal moisture conditions. In turn, the other study site (B) is located on flat moraine upland with natural conditions of soil moisture, poor quality of soils and hypsometry which may be taken into consideration in possible establishing of SFPs for the purpose of enriching the agricultural landscape.

\section{Selected spatial characteristics of SFPs}

The ecological processes and species richness of agricultural landscape is affected by, among others, the size of SFPs, their shape and distribution against one another (Magura et al., 2001; Moser et al., 2002; Decocq et al., 2016). In the case of the smallest patches, the effect of the shape was found to be slight, however, in the case of larger objects, the complexity of the shape shows a significant effect on biodiversity (Heegaard et al., 2007).

The selected spatial characteristics of patches are presented in Table 3. It is difficult to attribute the variability between the study sites to a single dominant landform. However, the analysis of size distribution of patches on individual study sites shows a certain relationships. In all analysed study sites, similarly to post-glacial areas in North America (Host and White, 2003), there was a strong representation of lower size classes. Regardless of the origin, in all study sites there was a dominance of small patches of an area below 5 ha. The smallest $(<2.5$ ha) occurred most often on hummocky uplands (Fig. 8), which can be attributed to frequent occurrence of small enclaves with different habitat conditions such as waterlogged land depressions, steep slopes and small patches of soils of poor quality. In undulating moraine area, and particularly in the area of flat moraine, larger patches (2.5-5.0) connected with relatively larger zones of depression and steep slopes were predominant.

In the study sites located on flat and undulating uplands, the highest mean size of the patches was found for the objects the origin of which was connected with the hypsometric factor (Table 4). These patches were characterised by the highest value of development index (Circle MN). This was mainly due to the presence of larger forest patches located in the area of longitudinal slopes surrounding the lakes and river valleys. In this group of patches, the highest mean values of Circle_MN index was found for SFPs in the study site Ia (0.67). In the hummocky upland area, the patches occurrence of which was related to hypsometry, showed relatively smaller size despite the most frequent occurrence. This can be connected with a small degree of radial relief of these areas and, consequently, relatively small and compact slope area of significant inclination.

Table 3. Selected metrics of SFPs within the study sites area

\begin{tabular}{c|c|c|c|c|c}
\hline Dominated landform & $\begin{array}{c}\text { Study } \\
\text { area }\end{array}$ & Amount & $\begin{array}{c}\text { Average area } \\
{[\mathbf{h a}]}\end{array}$ & $\begin{array}{c}\text { NNS* } \\
{[\mathbf{k m}]}\end{array}$ & NNI** \\
\hline \multirow{2}{*}{ I flat upland moraine } & Ia & 224 & 3.7 & 523.7 & 0.86 \\
& Ib & 231 & 5.8 & 544.8 & 0.74 \\
\hline \multirow{2}{*}{ II undulating upland moraine } & IIa & 168 & 5.1 & 618.3 & 0.80 \\
& IIb & 181 & 3.7 & 594.6 & 0.78 \\
\hline \multirow{2}{*}{ III hummocky upland moraine } & IIIa & 163 & 4.8 & 656.0 & 0.87 \\
& IIIb & 270 & 3.3 & 468.8 & 0.77 \\
\hline
\end{tabular}

*Nearest neighbour distance; **nearest neighbour index 


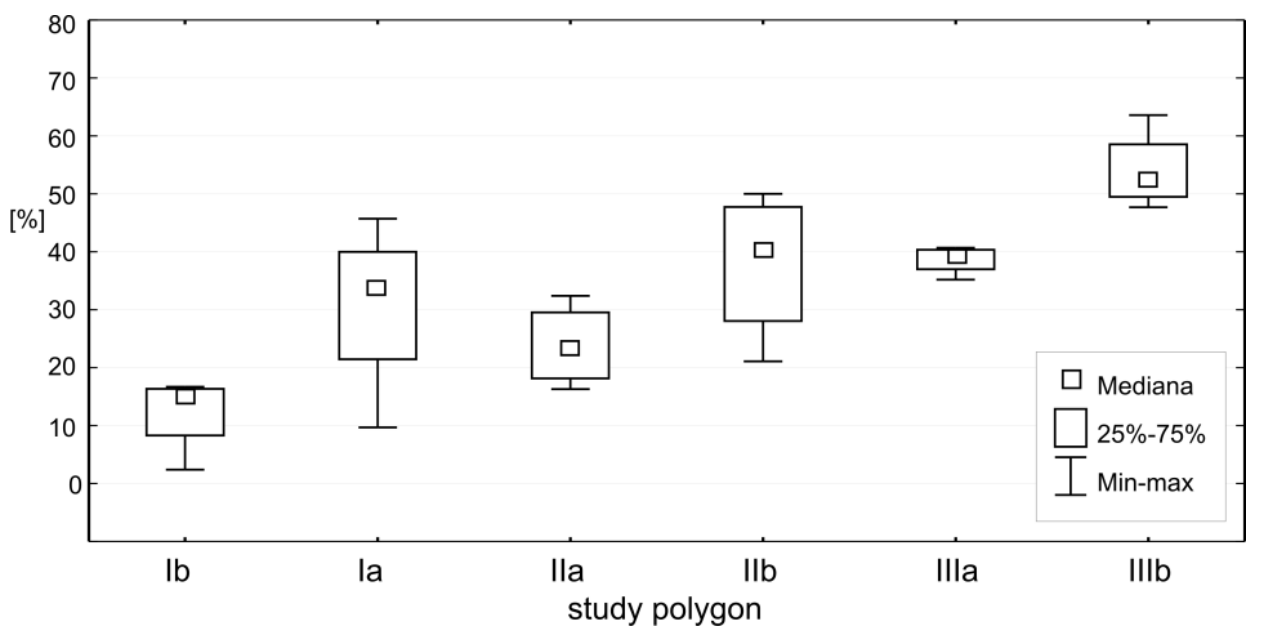

Figure 8. Share of small patches $(0.2-2 \mathrm{ha})$ within the study sites area

Table 4. Landscape metrics of forest patches with different genesis (explanations see Table 2)

\begin{tabular}{|c|c|c|c|c|c|c|}
\hline Factor & $\begin{array}{c}\text { Study } \\
\text { polygon }\end{array}$ & Amount & $\begin{array}{c}\text { Mean area of } \\
\text { patches } \\
\text { AREA_MN } \\
\text { [ha] }\end{array}$ & $\begin{array}{l}\text { Metrics of the } \\
\text { shape of patches } \\
\text { CIRCLE_ MN }\end{array}$ & $\begin{array}{c}\text { Nearest } \\
\text { neighbour } \\
\text { distance } \\
\text { NNS [m] }\end{array}$ & $\begin{array}{c}\text { Nearest } \\
\text { neighbour } \\
\text { index } \\
\text { NNI }\end{array}$ \\
\hline \multirow{6}{*}{$\begin{array}{l}\text { Wetness } \\
\text { (W) }\end{array}$} & Ia & 127 & 5.6 & 0.55 & 688.8 & 0.79 \\
\hline & $\mathrm{Ib}$ & 96 & 3.1 & 0.58 & 738.5 & 0.76 \\
\hline & IIa & 70 & 4.8 & 0.55 & 1023.2 & 0.85 \\
\hline & IIb & 68 & 3.5 & 0.53 & 927.9 & 0.86 \\
\hline & IIIa & 54 & 4.6 & 0.53 & 1029.4 & 0.81 \\
\hline & $\mathrm{IIb}$ & 71 & 3.6 & 0.56 & 786.7 & 0.74 \\
\hline \multirow{6}{*}{$\begin{array}{l}\text { Relief } \\
(\mathrm{H})\end{array}$} & Ia & 42 & 7.4 & 0.67 & 1090.3 & 0.75 \\
\hline & $\mathrm{Ib}$ & 31 & 6.4 & 0.62 & 1601.8 & 0.99 \\
\hline & IIa & 49 & 5.9 & 0.61 & 1353.2 & 0.90 \\
\hline & $\mathrm{IIb}$ & 57 & 6.2 & 0.61 & 870.7 & 0.79 \\
\hline & IIIa & 67 & 4.4 & 0.53 & 1052.4 & 0.98 \\
\hline & IIIb & 149 & 4.0 & 0.58 & 624.7 & 0.77 \\
\hline \multirow{6}{*}{$\begin{array}{l}\text { Soil } \\
\text { (S) }\end{array}$} & Ia & 50 & 4.7 & 0.50 & 1013.7 & 0.83 \\
\hline & $\mathrm{Ib}$ & 83 & 3.6 & 0.56 & 846.6 & 0.79 \\
\hline & IIa & 34 & 5.3 & 0.56 & 1243.3 & 0.72 \\
\hline & $\mathrm{IIb}$ & 40 & 3.8 & 0.53 & 1301.5 & 1.03 \\
\hline & IIIa & 27 & 5.6 & 0.55 & 1621.9 & 0.91 \\
\hline & IIIb & 39 & 3.6 & 0.56 & 1491.8 & 0.88 \\
\hline \multirow{6}{*}{$\begin{array}{l}\text { Other } \\
\text { (O) }\end{array}$} & Ia & 12 & 3.3 & 0.46 & 4359.4 & 1.57 \\
\hline & $\mathrm{Ib}$ & 14 & 2.8 & 0.54 & 2086.3 & 0.96 \\
\hline & IIa & 15 & 4.3 & 0.48 & 3991.2 & 1.12 \\
\hline & IIb & 16 & 2.4 & 0.49 & 3326.7 & 0.95 \\
\hline & IIIa & 15 & 3.7 & 0.51 & 2256.2 & 1.17 \\
\hline & IIIlb & 11 & 1.8 & 0.46 & 3924.5 & 1.08 \\
\hline
\end{tabular}


In all of the six analysed study sites, the patches categorised as "other" were characterised by the most compact size (circle-like). The values of Circle_MN index determined for the study sites Ia and IIb was only 0.46 .

The mean distance to the nearest neighbour (NNS) was predominantly dependent on the number of patches in a given group. Accordingly, the smallest distance between the patches was found for the group of the most frequently occurring objects related to hypsometry in the study site IIIb $(624.7 \mathrm{~m})$. The greatest distance was found with respect to anthropogenic objects in the same study site $(3924.5 \mathrm{~m})$.

The values of the NNI index showing cluster nature of the analysed patches, ranged from 0.72 (IIa; factor S) to 1.57 (Ia, factor: O). Grouping of patches was found mainly for the patches occurrence of which was due to land wetness. The greatest dispersion of patches was found for the category of "other". This can be explained by their anthropogenic origin, not related to physiographical variability of the given area.

\section{Conclusion}

Until recently, agricultural landscape management constituted a compromise between "environment" and "development". However, recently more attention is paid to ecological and social benefits of actions undertaken as a part of landscape management (de Groot et al., 2010). Many currently developed agri-environmental programmes entail an increase in the amount and quality of forests within such areas. Still, information enabling the development of practical guidelines regarding the optimum spatial design is relatively scarce (Fuentes-Montemayor et al., 2012). Developing appropriate guidelines and implementing informed landscape policy is hindered by the fact that agricultural landscape in Europe alone is characterised by great variability due to, among others, climate, habitat as well as agricultural management (Van Zanten et al., 2014). Particularly the post-glacial areas are characterised by major differences concerning the forms determining the current fragmentation of forest area (Najwer et al., 2016). Therefore, all actions related to achieving optimum visual and spatial structure of landscapes should be implemented individually for such areas and take into consideration their physiographical features. This also concerns the practice of enriching the monotonous agricultural areas with small landscape elements, including small forest patches. Knowledge on abiotic elements which constitute, or may constitute, potential habitats for small forest patches is limited. There is a lack of information concerning the spatial patterns of fragmentation (patch isolation, size and edge), and on practical use of such patterns in implementation of agri-environmental programmes as well as price estimation of ecosystem services (Valdés et al., 2015). Good knowledge of spatial characteristics of particular abiotic elements, which could potentially form habitats for SFPs on diverse geomorphological units, may also be beneficial in the analysis of landscape transformation trends due to climate change, transformation of economic conditions and technological progress.

Within the analysed post-glacial area, the abiotic elements determining the presence of SFPs are mainly: gradient of slopes, occurrence of patches of sandy soils and land wetness. However, the share of these elements in particular land forms is different. On flat and rolling morainic uplands, the most frequent reason behind the occurrence of SFPs is land wetness, whereas on undulating morainic uplands the patches related to land slopes are predominant. It could be assumed that on flat upland moraine in particular, the forecasted climatic change (Erwin, 2009; Samaniego et al., 2018) could 
be a decisive factor in excessive drying of small non-runoff depressions and facilitate transformation of these previously forested areas for agricultural use. The fact that the size of the SFPs occurring on that area is relatively small can only expedite this process. In turn, global warming and the resulting lowering of groundwater level (Taylor et al., 2013) most likely will not have a significant effect on the number of SFPs on hummocky upland, as on these areas the presence of SFPs is mostly connected with land relief. Regardless of geomorphological unit, excessive drying of patches of poor soil may lead to their exclusion from agricultural use and, as a result, spontaneous forestation and occurrence of shrubs - the fact already reported in some areas in Poland (Śmigielski et al., 2017).

Meeting the increasing demand for agricultural lands without disturbing the biological diversity is indeed a challenge for the $21^{\text {st }}$ century in lowland agricultural landscapes (Decocq et al., 2016). Therefore, knowledge on the elements determining the occurrence of SFPs may also prove useful in identifying the optimum locations for the establishing of new forest patches in a view of minimisation of resulting economic costs. Increasing availability of a given area's resources resulting from, among others, the INSPIRE Directive, allows faster selecting of such habitats especially, as was identified in the present paper, due to the fact that that the post-glacial landscape of Western Pomerania offers a big potential for creation of such habitats. The authors believe that the obtained results may be useful in planning the design of agricultural landscapes for sustainable and resilient biodiversity. Information on the post-glacial areas potential for establishing small landscape elements and the analysis of spatial conditions should be considered as one of the key criteria in decision making process regarding enriching the monotonous agricultural landscape.

\section{REFERENCES}

[1] Agger, P., Brandt, J. (1988): Dynamics of small biotopes in Danish agricultural landscapes. - Landscape Ecology 1(4): 227-240.

[2] Agriculture Report (2017): Bioligical Diversity and Agriculture Landscapes. - Federal Ministry for the Environment, Nature Conservation, Building and Nuclear Safety (BMUB), Bonn.

[3] Arriaza, M., Cañas-Ortega, J. F., Cañas-Madueño, J. A., Ruiz-Aviles, P. (2004): Assessing the visual quality of rural landscapes. - Landscape and Urban Planning 69(1): 115-125.

[4] Baudry, J., Bunce, R. G. H., Burel, F. (2000): Hedgerows: An international perspective on their origin, function and management. - Journal of Environmental Management 60(1): 7-22.

[5] Bell, S., Nikodemus, O., Peneze, Z., Kruze, I. (2009): Management of cultural landscapes: what does this mean in the former Soviet Union? A case study from Latvia. Landscape Research 34(4): 425-455.

[6] Benoit, M., Rizzo, E., Marraccini, A., Camilla, M., Enrico, B. (2012): Landscape agronomy: a new field for addressing agricultural landscape dynamics. - Landscape Ecology 27: 1385-1394.

[7] Brown, N., Fisher, R. (2009): Trees Outside Woods. - A Woodland Trust Publication, Grantham, UK.

[8] Burger, W., Burger, L. (2005): Conservation buffers. - Wildlife Trends 5(2): 2-8.

[9] Ciesielska, K., Ciesielski, M. (2017): Forest cover in different territorial profiles. Wiadomości Statystyczne 5(672): 62-78. 
[10] Crow, T. R., Host, G. E., Mladenoff, D. J. (1999): Ownership and ecosystem as sources of spatial heterogeneity in a forested landscape, Wisconsin, USA. - Landscape Ecology 14(5): 449-463.

[11] Decocq, G., Andrieu, E., Brunet, J., Chabrerie, O., De Frenne, P., De Smedt, P., Deconchat, M., Diekmann, M., Ehrmann, S., Giffard, B., Mifsud, E. G., Hansen, K., Hermy, M., Kolb, A., Lenoir, J., Liira, J., Moldan, F., Prokofieva, I., Rosenqvist, L., Varela, E., Valdés, A., Verheyen, K., Wulf, M. (2016): Ecosystem Services from Small Forest Patches in Agricultural Landscapes. - Current Forestry Reports 2(1): 30-44.

[12] De Groot, R. (2006): Function-analysis and valuation as a tool to assess land use conflicts in planning for sustainable, multi-functional landscapes. - Landscape and Urban Planning 75(3-4): 175-186.

[13] De Groot, R. S., Alkemade, R., Braat, L., Hein, L., Willemen, L. (2010): Challenges in integrating the concept of ecosystem services and values in landscape planning, management and decision making. - Ecological Complexity 7(3): 260-272.

[14] Erickson, D. L., Ryan, R. L., De Young, R. (2002): Woodlots in the rural landscape: Landowner motivations and management attitudes in a Michigan (USA) case study. Landscape and Urban Planning 58(2-4): 101-112.

[15] Erwin, K. L. (2009): Wetlands and global climate change: The role of wetland restoration in a changing world. - Wetlands Ecology and Management 17(1): 71-84.

[16] Estreguil, C., Caudullo, G., de Rigo, D., San-Miguel-Ayanz, J. (2013): Forest landscape in Europe: pattern, fragmentation and connectivity. - EUR Scientific and Technical Research 25717: 1-18.

[17] European Environment Agency (2017): Unsustainable land use threatens European landscapes, Copenhagen. - www.eea.europa.eu/highlights/ unsustainable-land-usethreatens-european-landscapes.

[18] Farah, F. T., Muylaert, R. de L., Ribeiro, M. C., Ribeiro, J. W., Mangueira, J. R. de S. A., Souza, V. C., Rodrigues, R. R. (2017): Integrating plant richness in forest patches can rescue overall biodiversity in human-modified landscapes. - Forest Ecology and Management 397: 78-88.

[19] Fuentes-Montemayor, E., Goulson, D., Cavin, L., Wallace, J. M., Park, K. J. (2012): Factors influencing moth assemblages in woodland fragments on farmland: Implications for woodland management and creation schemes. - Biological Conservation 153: 265-275.

[20] Gamrat, R., Gałczyńska, M. (2014): Influence of the forest ecotone structure on the phytodiversity. - Sylwan 158(1): 34-40 (in Polish).

[21] Gibbons, P., Lindenmayer, D. B., Fischer, J., Manning, A. D., Weinberg, A., Seddon, J., Ryan, P., Barrett, G. (2008): The future of scattered trees in agricultural landscapes. Conservation Biology 22(5): 1309-1319.

[22] Graae, B. J. (2000): The effect of landscape fragmentation and forest continuity on forest floor species in two regions of Denmark. - Journal of Vegetation Science 11(6): 881-892.

[23] Heegaard, E., Økland, R. H., Bratli, H., Dramstad, W. E., Engan, G., Pedersen, O., Solstad, H. (2007): Regularity of species richness relationships to patch size and shape. Ecography 30(4): 589-597.

[24] Hermes, J., Albert, C., von Haaren, C. (2018): Assessing the aesthetic quality of landscapes in Germany. - Ecosystem Services 31: 296-307.

[25] Hietel, E., Waldhardt, R., Otte, A. (2004): Analysing land-cover changes in relation to environmental variables in Hesse, Germany. - Landscape Ecology 19(5): 473-489.

[26] Host, G. E., White, M. A. (2003): Contemporary forest composition and spatial patterns of north central and northeastern Minnesota: an assessment using 1990s Landsat data. Minnesota Forest Resources Council Report LT-1203b, Duluth.

[27] Iverson, L. R. (1988): Land-use changes in Illinois, ASA: The influence of landscape attributes on current and historic land use. - Landscape Ecology 2(1): 45-61. 
[28] Jongman, R. H. G. (2002): Homogenisation and fragmentation of the European landscape: Ecological consequences and solutions. - Landscape and Urban Planning 58(2-4): 211-221.

[29] Kühne, S. et al. (2018): Hecken und Raine in der Agrarlandschaft - Bedeutung, Neuanlage, Pflege. - Bundesanstalt für Landwirtschaft und Ernährung, Bonn.

[30] Landis, D. A. (2017): Designing agricultural landscapes for biodiversity-based ecosystem services. - Basic and Applied Ecology 18: 1-12.

[31] Lenschow, U. (2005): Landschaftsökologische Grundlagen zum Schutz, zur Pflege und zur Neuanlage von Feldhecken in Mecklenburg-Vorpommern. - Landesamt für Umwelt, Naturschutz und Geologie, Güstrow.

[32] Lindgren, J. (2017): Small remnant habitas. Important structures in fragmented landscapes. $\quad-\quad$ Stockholm University. http://www.divaportal.org/smash/record.jsf?pid=diva2\%3A1154654\&dswid=-814.

[33] Magura, T., Ködöböcz, V., Tóthmérész, B. (2001): Effects of habitat fragmentation on carabids in forest patches. - Journal of Biogeography 25: 129-138.

[34] Michel, N., Burel, F., Legendre, P., Butet, A. (2007): Role of habitat and landscape in structuring small mammal assemblages in hedgerow networks of contrasted farming landscapes in Brittany, France. - Landscape Ecology 22(8): 1241-1253.

[35] Moser, D., Zechmeister, H. G., Plutzar, C., Sauberer, N., Wrbka, T., Grabherr, G. (2002): Landscape patch shape complexity as an effective measure for plant species richness in rural landscapes. - Landscape Ecology 17(7): 657-669.

[36] Myga-Piątek, U. (2010): Transformation of cultural landscapes in the light of the idea of sustainable development. - Problems of Sustainable Development 5(1): 95-108.

[37] Myga-Piątek, U. (2012): Cultural Landscapes. Evolutionary and Typological Aspects. University of Silesia, Katowice (in Polish).

[38] Najwer, A., Borysiak, J., Gudowicz, J., Mazurek, M., Zwoliński, Z. (2016): Geodiversity and biodiversity of the postglacial landscape (Dębnica River Catchment, Poland). Quaestiones Geographicae 35(1): 5-28.

[39] Pieńkowski, P. (2008): Distribution of small, water-filled depressions as a component of the analysis of icesheet retreat dynamics in young glacial areas. - Landform Analysis 6: 41-46.

[40] Pieńkowski, P. (2015): Evaluation of the forest cover fragmentation in Western Pomerania. - Sylwan 159(7): 610-616 (in Polish).

[41] Pieńkowski, P., Podlasiński, M. (2002): Changes in forest cover of Szczecin Lowland from the 16th to the end of 20th century, in relation to soil cover. - Electronic Journal of Polish Agricultural Universities 5(2).

[42] Pieńkowski, P., Kupiec, M., Smoter, P. (2010): Changes of selected landscape components in neighbouring areas of Ina and Mała Ina catchments in 20th C. - Prace Komisji Krajobrazu Kulturowego 13: 54-62 (in Polish).

[43] Plit, J., Myga-Piątek, U. (2014): The degree of landscape openness as a manifestation of cultural metamorphose. - Quaestiones Geographicae 33(3): 145-154.

[44] Pospieszny, L. (2014): The Neolithic Landscapes of the Polish Lowlands. Earthen LongBarrows and Their Histories. - In: Asa, L. P.-D., Larsson, M. (eds.) Uniting Sea II Stone Age Societies in the Baltic Sea Region. Opia 51. Uppsala University, Uppsala, pp. 147-170.

[45] Power, A. G. (2010): Ecosystem services and agriculture: tradeoffs and synergies. Philosophical Transactions of the Royal Society B: Biological Sciences 365(1554): 29592971.

[46] Prus, B., Budz, Ł. (2015): Analysis of relief impact on land structure on an example of Nowy Targ District. - Infrastructure and Ecology of Rural Areas 2(II): 438-497.

[47] Romanova, E. A. (2015): Land use, settlement, and modern landscapes. - International Journal of Economics and Financial Issues 5(5): 25-29. 
[48] Ryszkowski, L., Karg, J., Bernacki, Z. (2003): Biocenotic function of the midfield woodlots in west Poland: Study area and research assumptions. - Polish Journal of Ecology 51(3): 269-281.

[49] Samaniego, L., Thober, S., Kumar, R., Wanders, N., Rakovec, O., Pan, M., Zink, M., Sheffield, J., Wood, E. F., Marx, A. (2018): Anthropogenic warming exacerbates European soil moisture droughts. - Nature Climate Change 8(5): 421-426.

[50] Schaich, H., Bieling, C., Plieninger, T. (2010): Linking ecosystem services with cultural landscape research. - GAIA - Ecological Perspectives for Science and Society 19(4): 269-277.

[51] Śmigielski, M., Pijanowski, J. M., Gniadek, J. (2017): Forest succession and afforestation of agricultural land as a current challenge agricultural works. - Acta Sci. Pol. Formatio Circumiectus 16(4): 51-63.

[52] Smith, S., Bruce, C. (2008): CrimeStat III. Workbook. - The National Institute of Justice, Washington.

[53] Solon, J., Roo-Zielińska, E., Affek, A., Kowalska, A., Kruczkowska, B., Wolski, J., Degórski, M., Grabińska, B., Kołaczkowska, E., Regulska, E., Zawiska, I. (2017): Ecosystem Services in a Postglacial Landscape - Assessment of Potential and Utilisation. Institute of Geography and Spatial Organization, PAS, Warsaw.

[54] Stanton, R. L., Morrissey, C. A., Clark, R. G. (2018): Analysis of trends and agricultural drivers of farmland bird declines in North America: a review. - Agriculture, Ecosystems and Environment 254: 244-254.

[55] Taylor, R. G., Scanlon, B., Döll, P., Rodell, M., Van Beek, R., Wada, Y., Longuevergne, L., Leblanc, M., Famiglietti, J. S., Edmunds, M., Konikow, L., Green, T. R., Chen, J., Taniguchi, M., Bierkens, M. F. P., Macdonald, A., Fan, Y., Maxwell, R. M., Yechieli, Y., Gurdak, J. J., Allen, D. M., Shamsudduha, M., Hiscock, K., Yeh, P. J. F., Holman, I., Treidel, H. (2013): Ground water and climate change. - Nature Climate Change 3(4): 322-329.

[56] Valdés, A., Lenoir, J., Gallet-Moron, E., Andrieu, E., Brunet, J., Chabrerie, O., ClossetKopp, D., Cousins, S. A. O., Deconchat, M., De Frenne, P., De Smedt, P., Diekmann, M., Hansen, K., Hermy, M., Kolb, A., Liira, J., Lindgren, J., Naaf, T., Paal, T., Prokofieva, I., Scherer-Lorenzen, M., Wulf, M., Verheyen, K., Decocq, G. (2015): The contribution of patch-scale conditions is greater than that of macroclimate in explaining local plant diversity in fragmented forests across Europe. - Global Ecology and Biogeography 24(9): 1094-1105.

[57] Van Berkel, D. B., Verburg, P. H. (2014): Spatial quantification and valuation of cultural ecosystem services in an agricultural landscape. - Ecological Indicators 37(A): 163-174.

[58] Van Zanten, B. T., Verburg, P. H., Espinosa, M., Gomez-Y-Paloma, S., Galimberti, G., Kantelhardt, J., Kapfer, M., Lefebvre, M., Manrique, R., Piorr, A., Raggi, M., Schaller, L., Targetti, S., Zasada, I., Viaggi, D. (2014): European agricultural landscapes, common agricultural policy and ecosystem services: a review. - Agronomy for Sustainable Development 34(2): 309-325.

[59] Van Zanten, B. T., Zasada, I., Koetse, M. J., Ungaro, F., Häfner, K., Verburg, P. H. (2016): A comparative approach to assess the contribution of landscape features to aesthetic and recreational values in agricultural landscapes. - Ecosystem Services 17: 8798.

[60] Varela, E., Verheyen, K., Valdés, A., Soliño, M., Jacobsen, J. B., De Smedt, P., Ehrmann, S., Gärtner, S., Górriz, E., Decocq, G. (2018): Promoting biodiversity values of small forest patches in agricultural landscapes: Ecological drivers and social demand. - Science of the Total Environment 619-620: 1319-1329.

[61] Vejre, H., Brandt, J. (2004): Contemporary Danish landscape research. - Belgeo (23): 223-230.

[62] Wuczyński, A. (2016): Farmland bird diversity in contrasting agricultural landscapes of southwestern Poland. - Landscape and Urban Planning 148: 108-119 (in Polish). 
[63] Wulf, M., Sommer, M., Schmidt, R. (2010): Forest cover changes in the Prignitz region (NE Germany) between 1790 and 1960 in relation to soils and other driving forces. Landscape Ecology 25(2): 299-313.

[64] Yahner, R. H. (1986): Structure, seasonal dynamics, and habitat relationships of avian communities in small even-aged forest stands. - Wilson Bulletin 98(1): 61-82.

[65] Zając, S., Kaliszewski, A., Młynarski, W. (2014): Forests and forestry in Poland and other EU countries. - Folia Forestalia Polonica, Series A 56(4): 185-193.

[66] Zajączkowski, K. (2005): Regionalization of Agricultural Landscape Needs or Shelterbelts and Woodlots in Poland. - Forest Research Institute, Warsaw (in Polish).

[67] Żarska, B., Fornal-Pieniak, B., Zaraś-Januszkiewicz, E. (2016): Areas designated for afforestation and areas excluded from afforestation - selected aspects related to the protection of the landscape in view of Poland experience. - Ecological Questions 22: 17-22. 